IIIIIIIIIIIIIIIIIIIIIIIIIIIIIIIIIIIII

Technical Report

IIIIIIIIIIIIIIIIIIIIIIIIIIIIIIIIIIII

\title{
Summary of Toxicity Studies with Flutianil
}

\author{
Naoki IkemI,* Sachi Kimura, Yasuhiro Endo and Hisashi OKA \\ Research and Development Division, OAT Agrio Co., Ltd., 615 Hanamen, Satoura, Naruto, Tokushima, 772-0021 Japan
}

(Received February 25, 2019; Accepted July 28, 2019)

\begin{abstract}
We have evaluated the toxicity of flutianil, which was developed by OAT Agrio. Flutianil shows low toxicity, no carcinogenicity, no reproductive toxicity, and no genotoxicity. Based on these results, the ADI of flutianil has been set at $2.4 \mathrm{mg} / \mathrm{kg} \mathrm{bw} /$ day with a safety factor of 100 .

Keywords: flutianil, toxicity.
\end{abstract}

\section{Introduction}

Powdery mildew is one of the most serious disease groups in agricultural production. Many chemicals have been developed as commercial fungicides for the control of powdery mildew. However, the appearance of strains resistant to commercial fungicides among the pathogens causing powdery mildew has led to poor disease control.

A novel fungicide, flutianil, (2Z)-\{[2-fluoro-5-(trifluoromethyl)phenyl] thio\} [3-(2-methoxyphenyl)-1,3-thiazolidin2-ylidene] acetonitrile (Code Name: OK-5203) (Fig. 1), shows excellent control of powdery mildew in various plants. Flutianil belongs to a cyano-methylene thiazolidine group that represents a new class of chemicals associated with the control of powdery mildew. Flutianil has a novel mode of action against powdery mildew, which is classified under the Fungicide Resistance Action Committee (FRAC) code U 13. No cross-resistance with other chemical classes has been reported.

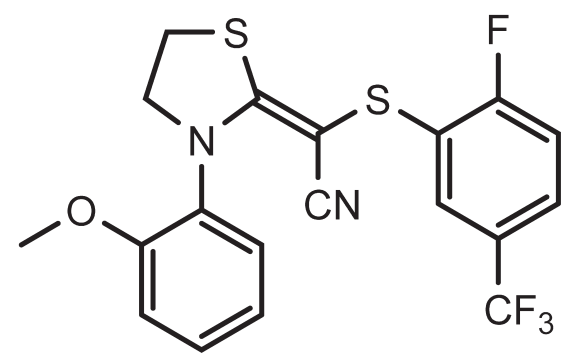

Fig. 1. Chemical structure of flutianil.

\footnotetext{
* To whom correspondence should be addressed.

E-mail: naoki.ikemi@oat-agrio.co.jp

Published online October 22, 2019
}

(c) BY-NC-ND (c) Pesticide Science Society of Japan 2019. This is an open access article distributed under the Creative Commons AttributionNonCommercial-NoDerivatives 4.0 International (CC BY-NC-ND 4.0) License (https://creativecommons.org/licenses/by-nc-nd/4.0/)

Flutianil has the following physical and chemical properties.

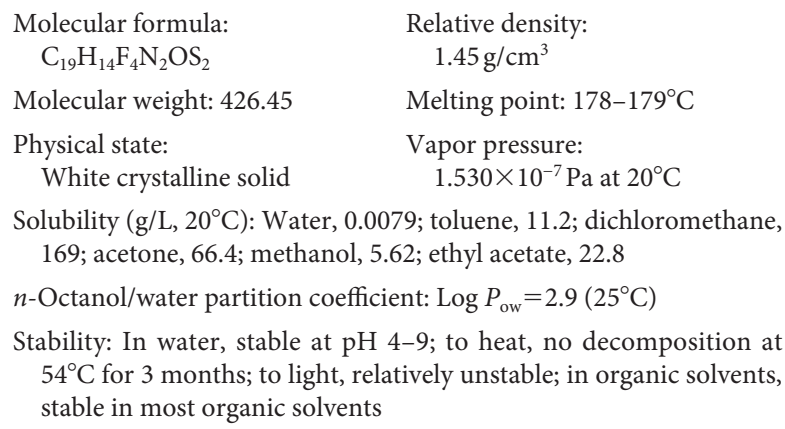
$54^{\circ} \mathrm{C}$ for 3 months; to light, relatively unstable; in organic solvents, stable in most organic solvents

\section{Results and Discussion}

Acute toxicity study $y^{1-3)}$

Acute toxicity studies in rats were conducted for technical-grade flutianil. Table 1 shows the results. No mortality was observed at the limit dose in any dosing route.

Skin and eye irritation and skin sensitization ${ }^{4-6)}$

Skin and eye irritation tests were conducted in Japanese white rabbits with the result that very mild eye irritation but no skin irritation was observed.

A skin sensitization test (maximization method) was conducted in Hartley guinea pigs. The result was negative.

\section{Subacute toxicity studies}

Ninety-day subacute toxicity study (rats $)^{7)}$

A subacute toxicity study was conducted in Wistar rats (10 males and 10 females per group) fed diets containing flutianil (technical grade: 0, 20, 200, 2000, and 20000 ppm; see Table 2 for average flutianil consumption) for 90 days.

In the histopathological examination, deposition of hyaline droplets in epithelial cells of the renal proximal tubule was observed in the kidney of males in all study groups, including the control group. No significant difference was observed in the fre- 
Table 1. Summary of the acute toxicity studies

\begin{tabular}{|c|c|c|c|c|}
\hline \multirow{2}{*}{$\begin{array}{l}\text { Admin- } \\
\text { istration } \\
\text { route }\end{array}$} & \multirow{2}{*}{ Animal } & \multicolumn{2}{|c|}{$\mathrm{LD}_{50}(\mathrm{mg} / \mathrm{kg} \mathrm{bw})$} & \multirow{2}{*}{ Observed symptoms } \\
\hline & & Male & Female & \\
\hline Oral & $\begin{array}{l}\text { Wistar rat } \\
3 \text { females }\end{array}$ & - & $>5000$ & $\begin{array}{l}\text { Neither symptom nor } \\
\text { death }\end{array}$ \\
\hline Dermal & $\begin{array}{l}\text { Wistar rat } \\
5 \text { males and } \\
5 \text { females }\end{array}$ & $>5000$ & $>5000$ & $\begin{array}{l}\text { Neither symptom nor } \\
\text { death }\end{array}$ \\
\hline $\begin{array}{l}\text { Inhala- } \\
\text { tion }\end{array}$ & $\begin{array}{l}\text { Wistar rat } \\
5 \text { males and } \\
5 \text { females }\end{array}$ & $\begin{array}{r}\mathrm{LC}_{50}( \\
>5.17\end{array}$ & $\begin{array}{l}\text { (L) } \\
\quad>5.17\end{array}$ & $\begin{array}{l}\text { Staining of the head, } \\
\text { stained fur, staining } \\
\text { of nose and back, un- } \\
\text { kempt fur, abnormal } \\
\text { phonation. No death }\end{array}$ \\
\hline
\end{tabular}

quency of this lesion among the dose groups. However, analysis of the degree of the lesion revealed a significant increase in moderate deposition at $20000 \mathrm{ppm}$ and an increasing tendency at $2000 \mathrm{ppm}$. Immunohistochemical staining demonstrated that the hyaline droplets in the proximal tubular cells were positive for $\alpha 2 \mu$-globulin. It is known that the accumulation of $\alpha 2 \mu$-globulin may cause the occurrence of chronic progressive nephropathy in male rats. ${ }^{8)}$ Generally, $\alpha 2 \mu$-globulin nephropathy is regarded as a specific lesion in male rats that is not relevant to humans because of the absence of such protein production. $^{8-10)}$

Considering an increase in relative weight of the liver and centrilobular hypertrophy of hepatocytes in males at $20000 \mathrm{ppm}$ and no toxicological finding in females at any dose, the NOAEL (No Observable Adverse Effect Level) in this study was considered to be $2000 \mathrm{ppm}(122 \mathrm{mg} / \mathrm{kg} \mathrm{bw} /$ day $)$ for males and $20000 \mathrm{ppm}(1500 \mathrm{mg} / \mathrm{kg} \mathrm{bw} /$ day $)$, the highest dose in this study, for females.

Ninety-day subacute toxicity study (mice $)^{11)}$

A subacute toxicity study was conducted in ICR mice (10 males and 10 females per group) fed diets containing flutianil (technical grade: $0,1000,3000$, and 10000 ppm; see Table 3 for average flutianil consumption) for 90 days.

As there were no toxicological findings in any dose group, the NOAEL in this study was considered to be $10000 \mathrm{ppm}$, the highest dose in this study, for males and females (males: $1390 \mathrm{mg} /$ $\mathrm{kg}$ bw/day; females: $1560 \mathrm{mg} / \mathrm{kg}$ bw/day).

Ninety-day subacute toxicity study $(\text { dogs })^{12}$

A subacute toxicity study was conducted in beagles (4 males and 4 females per group) receiving an oral capsule (technical grade: $0,30,300$, and $1000 \mathrm{mg} / \mathrm{kg} \mathrm{bw} /$ day) for 90 days.

As there were no toxicological findings in any dose group, the

Table 2. Average Flutianil consumption in the 90-day subacute toxicity study (rats)

\begin{tabular}{cccccc}
\hline Dose & & $20 \mathrm{ppm}$ & $200 \mathrm{ppm}$ & $2000 \mathrm{ppm}$ & $20000 \mathrm{ppm}$ \\
\hline $\begin{array}{c}\text { Average Flutianil } \\
\text { consumption } \\
(\mathrm{mg} / \mathrm{kg} \text { bw/day })\end{array}$ & Male & 1.22 & 12.5 & 122 & 1270 \\
\cline { 2 - 6 } & Female & 1.46 & 14.3 & 149 & 1500 \\
\hline
\end{tabular}

NOAEL in this study was considered to be $1000 \mathrm{mg} / \mathrm{kg}$ bw/day, the highest dose in this study, for males and females.

Twenty-eight-day subacute dermal toxicity study $(\text { rats })^{13)}$

A subacute dermal toxicity study was conducted in Wistar rats (10 males and 10 females per group) receiving dermal $(0,100$, 500 , and $1000 \mathrm{mg} / \mathrm{kg} \mathrm{bw} /$ day; $6 \mathrm{hr} /$ day) administration for 28 days. The animals in the control group and the $1000 \mathrm{mg} / \mathrm{kg} \mathrm{bw} /$ day group were given a 14-day recovery period following the completion of 28-day administration.

As there were no toxicological findings in any dose group, the NOAEL in this study was considered to be $1000 \mathrm{mg} / \mathrm{kg}$ bw/day, the highest dose in this study, for males and females.

\section{Chronic toxicity/carcinogenicity}

One-year chronic toxicity study $(\text { dogs })^{14)}$

A chronic toxicity study was conducted in beagles (4 males and 4 females per group) receiving an oral capsule containing flutianil (technical grade: 0, 30, 300, and $1000 \mathrm{mg} / \mathrm{kg}$ bw/day) for 1 year.

As there were no toxicological findings in any dose group, the NOAEL in this study was considered to be $1000 \mathrm{mg} / \mathrm{kg}$ bw/day, the highest dose in this study, for males and females.

Combined 2-year chronic toxicity/carcinogenicity study (rats) ${ }^{15)}$ A combined chronic toxicity/carcinogenicity study was conducted in Wistar rats [main groups: 51 males and 51 females per group; interim sacrifice groups: 12 males and 12 females per group (21 males and 21 females in the highest dose group)] fed diets containing flutianil (technical grade: 0, 60, 600, 2000, and $6000 \mathrm{ppm}$ for males; $0,60,2000,6000$, and $20000 \mathrm{ppm}$ for females; see Table 4 for average flutianil consumption) for 2 years.

In the histopathological examination, deposition of hyaline droplets in epithelial cells of the renal proximal tubule was observed in the kidney of males in all study groups, including the control group. Though a significant increase was observed in the frequency in males at $2000 \mathrm{ppm}$ or higher doses at the interim sacrifice, no significant difference was observed at the final sacrifice. As a result of immunostaining, these lesions were confirmed to be attributable to $\alpha 2 \mu$-globulin deposition. As $\alpha 2 \mu$-globulin is not produced in humans, $\alpha 2 \mu$-globulin nephropathy is considered to be a lesion specific to male rats that is not related to humans. ${ }^{8-10)}$ In males at $6000 \mathrm{ppm}$, a significant decrease was observed in the interstitial edema of the testis, but a decrease in the frequency was considered to be toxicologically insignificant.

As there were no toxicological findings in any dose group, the NOAEL in this study was considered to be 6000 ppm (249 mg/ $\mathrm{kg}$ bw/day), the highest dose in this study, for males and

Table 3. Average Flutianil consumption in the 90-day subacute toxicity study (mice)

\begin{tabular}{ccccc}
\hline Dose & & $1000 \mathrm{ppm}$ & $3000 \mathrm{ppm}$ & $10000 \mathrm{ppm}$ \\
\hline $\begin{array}{c}\text { Average Flutianil } \\
\text { consumption } \\
(\mathrm{mg} / \mathrm{kg} \text { bw/day) }\end{array}$ & Male & 138 & 409 & 1390 \\
\cline { 3 - 5 } & Female & 159 & 481 & 1560 \\
\hline
\end{tabular}


Table 4. Average Flutianil consumption in the 2-year combined chronic toxicity/carcinogenicity

\begin{tabular}{ccccccc}
\hline Dose & & $\begin{array}{c}60 \\
\text { ppm }\end{array}$ & $\begin{array}{c}600 \\
\text { ppm }\end{array}$ & $\begin{array}{c}2000 \\
\text { ppm }\end{array}$ & $\begin{array}{c}6000 \\
\text { ppm }\end{array}$ & $\begin{array}{c}20000 \\
\text { ppm }\end{array}$ \\
\hline $\begin{array}{c}\text { Average Flutianil } \\
\text { consumption } \\
(\mathrm{mg} / \mathrm{kg} \text { bw/day })\end{array}$ & Male & 2.45 & 25.2 & 81.9 & 249 & - \\
\cline { 2 - 7 } & Female & 3.15 & - & 111 & 334 & 1130 \\
\hline
\end{tabular}

$20000 \mathrm{ppm}$ (1130 mg/kg bw/day) for females. Flutianil showed no carcinogenicity.

Eighteen-month carcinogenicity study $(\text { mice })^{16)}$

A carcinogenicity study was conducted in ICR mice (52 males and 52 females per group) fed diets containing flutianil (technical grade: $0,1000,3000$, and 10000 ppm; see Table 5 for average flutianil consumption) for 18 months.

As there were no toxicological findings in any dose group, the NOAEL in this study was considered to be $10000 \mathrm{ppm}$, the highest dose in this study, for males and females (males: $1084 \mathrm{mg} /$ $\mathrm{kg}$ bw/day; females: $1063 \mathrm{mg} / \mathrm{kg}$ bw/day). Flutianil showed no carcinogenicity.

\section{Reproductive/developmental toxicity}

Two-generation reproductive toxicity study $(\text { rats })^{17)}$

A two-generation reproductive toxicity study was conducted in Wistar rats (24 males and 24 females per group) fed diets containing flutianil (technical grade: 0, 200, 2000, and $20000 \mathrm{ppm}$; see Table 6 for average flutianil consumption).

Table 7 shows the toxicological findings observed in each treatment group.

In male and female parent animals in $\mathrm{P}$ and $\mathrm{F}_{1}$ generations, $\mathrm{a}$ significantly high value of food consumption was sporadically observed or was observed throughout the study period at doses of 2000 ppm or higher, but the high value of food consumption was judged to have no toxicological significance.

No effects on $F_{1}$ or $F_{2}$ offspring were observed in any treated group. Although the mean number of $F_{2}$ pups delivered in the 20000 ppm group (10.0) was significantly lower than that in the control group (11.8), the difference was considered to be incidental for the following reasons: the difference between the number of implantation sites in $F_{1}$ parental females and the number of $\mathrm{F}_{2}$ pups delivered, which corresponds to the total number of dead $\mathrm{F}_{2}$ embryos and fetuses, in the 20000 ppm group was comparable to that in the control group, suggesting that fetal resorptions and/or deaths were not induced in this group; the number of implantation sites in $F_{1}$ females of the $20000 \mathrm{ppm}$ group (11.0) was within the range of recent historical control data (11.0-13.8) obtained from 7 reproduction toxicity studies

Table 5. Average Flutianil consumption in the 18-month carcinogenicity study (mice)

\begin{tabular}{ccccc}
\hline Dose & & $1000 \mathrm{ppm}$ & $3000 \mathrm{ppm}$ & $10000 \mathrm{ppm}$ \\
\hline $\begin{array}{c}\text { Average Flutianil } \\
\text { consumption } \\
(\mathrm{mg} / \mathrm{kg} \text { bw/day })\end{array}$ & Memale & 106 & 321 & 1084 \\
\cline { 2 - 5 } & & 105 & 316 & 1063 \\
\hline
\end{tabular}

using the same strain of rats (2002-2006 in the Institute of Environmental Toxicology ${ }^{18)}$ ); and the mean number of ovarian primordial follicles of $F_{1}$ parental females in the $20000 \mathrm{ppm}$ group was comparable to that in the control group.

In the histopathological examination, deposition of hyaline droplets in the epithelial cells of the renal proximal tubule was observed in the kidney of males in all study groups, including the control group, and a significant increase was observed in the frequency in $\mathrm{P}$ males at doses of $2000 \mathrm{ppm}$ or higher. Though no significant lesion was observed in $F_{1}$ males, evaluation of the degree of difference revealed a significant increase in moderate deposition in $\mathrm{P}$ males at doses of $2000 \mathrm{ppm}$ or higher and in $\mathrm{F}_{1}$ males at $20000 \mathrm{ppm}$. The deposition of hyaline droplets in the epithelial cells of the renal proximal tubule was confirmed to be attributable to $\alpha 2 \mu$-globulin deposition in the 90 -day subacute toxicity study in rats ${ }^{11)}$ and the 2 -year combined chronic toxicity/carcinogenicity study. ${ }^{15)}$ As $\alpha 2 \mu$-globulin is not produced in humans, $\alpha 2 \mu$-globulin nephropathy is considered to be a lesion specific to male rats that is not related to humans.

Considering the increases in absolute and relative weights of the liver and so on in $\mathrm{P}$ and $\mathrm{F}_{1}$ males and females at $20000 \mathrm{ppm}$ for parent animals and no toxicological finding in any of the dose groups of offspring, the NOAEL in this study was considered to be $2000 \mathrm{ppm}$ for male and female parent animals (P male: $142 \mathrm{mg} / \mathrm{kg}$ bw/day; $\mathrm{P}$ female: $171 \mathrm{mg} / \mathrm{kg}$ bw/day; $F_{1}$ male: $155 \mathrm{mg} / \mathrm{kg}$ bw/day; $F_{1}$ female: $176 \mathrm{mg} / \mathrm{kg}$ bw/day) and $20000 \mathrm{ppm}$, the highest dose in this study, for offspring (P male: $1470 \mathrm{mg} / \mathrm{kg} \mathrm{bw} /$ day; $\mathrm{P}$ female: $1750 \mathrm{mg} / \mathrm{kg}$ bw/day; $\mathrm{F}_{1}$ male: $1580 \mathrm{mg} / \mathrm{kg}$ bw/day; $\mathrm{F}_{1}$ female: $1770 \mathrm{mg} / \mathrm{kg} \mathrm{bw} /$ day). Flutianil showed no effect on reproduction.

Developmental toxicity study $(\text { rats })^{19)}$

A developmental toxicity study was conducted in Wistar rats (25 females per group) receiving flutianil as an oral gavage dose (technical grade: $0,100,333$, and $1000 \mathrm{mg} / \mathrm{kg}$ bw/day; vehicle: $0.5 \%$ CMC aqueous solution) on days 6-19 of gestation.

As there were no toxicological findings related to administration of the drug in dams or fetuses in any of the dose groups, the NOAEL in this study was considered to be $1000 \mathrm{mg} / \mathrm{kg} \mathrm{bw} /$ day, the highest dose in this study, for dams and fetuses. Flutianil showed no teratogenicity.

Developmental toxicity study (rabbits) ${ }^{20)}$

A developmental toxicity study was conducted in NZW rabbits (25 females per group) receiving flutianil as an oral gavage dose (technical grade: $0,100,300$, and $1000 \mathrm{mg} / \mathrm{kg}$ bw/day; vehicle: $0.5 \% \mathrm{CMC}$ aqueous solution) on days $6-28$ of gestation.

Table 6. Average Flutianil consumption in the two-generation reproductive toxicity study (rats)

\begin{tabular}{|c|c|c|c|c|c|}
\hline \multicolumn{3}{|c|}{ Dose } & 200 ppm & \multicolumn{2}{|c|}{2000 ppm 20000 ppm } \\
\hline \multirow{4}{*}{$\begin{array}{l}\text { Average Flutianil } \\
\text { consumption } \\
\text { (mg/kgbw/day) }\end{array}$} & P generation & Male & 13.9 & 142 & 1470 \\
\hline & & Female & 16.6 & 171 & 1750 \\
\hline & $F_{1}$ generation & Male & 15.2 & 155 & 1580 \\
\hline & & Female & 17.1 & 176 & 1770 \\
\hline
\end{tabular}


Table 7. Toxicological findings observed in the two-generation reproductive study (rats)

\begin{tabular}{|c|c|c|c|c|c|}
\hline \multirow{2}{*}{\multicolumn{2}{|c|}{ Dose }} & \multicolumn{2}{|c|}{ Parent: $\mathrm{P}$, Offsprings: $\mathrm{F}_{1}$} & \multicolumn{2}{|c|}{ Parent: $\mathrm{F}_{1}$, Offsprings: $\mathrm{F}_{2}$} \\
\hline & & Male & Female & Male & Female \\
\hline \multirow[t]{4}{*}{ Parent animals } & $20000 \mathrm{ppm}$ & $\begin{array}{l}\text {-Increases in absolute and } \\
\text { relative weights of the liver }\end{array}$ & $\begin{array}{l}\text {-Increases in absolute and } \\
\text { relative weights of the liver }\end{array}$ & $\begin{array}{l}\text {-Increases in absolute and } \\
\text { relative weights of the liver }\end{array}$ & $\begin{array}{l}\text {-Increases in absolute and } \\
\text { relative weights of the liver }\end{array}$ \\
\hline & & $\begin{array}{l}\text {-Increases in absolute and } \\
\text { relative weights of the } \\
\text { adrenal gland }\end{array}$ & & & $\begin{array}{l}\text {-Increases in absolute and } \\
\text { relative weights of the } \\
\text { thyroid gland }\end{array}$ \\
\hline & & $\begin{array}{l}\text {-Centrilobular hepatocellular } \\
\text { hypertrophy }\end{array}$ & & & \\
\hline & $\leq 2000 \mathrm{ppm}$ & No toxicological finding & No toxicological finding & No toxicological finding & No toxicological finding \\
\hline Offsprings & $\leq 20000 \mathrm{ppm}$ & No toxicological finding & No toxicological finding & No toxicological finding & No toxicological finding \\
\hline
\end{tabular}

In the $1000 \mathrm{mg} / \mathrm{kgbw} /$ day group, although there was no statistically significant difference, an increase in the late embryo resorption rate per litter was observed; however, it was attributable to one dam that had resorbed only one embryo. In the group, hydrencephalus was observed as a visceral abnormality in 3 fetuses in a litter. The mean incidence of this abnormality per litter was $1.5 \%$, and no significant difference was observed in the frequency, but it exceeded the upper limit of the background data $(0.7 \%)$. However, based on the finding that 2 or 3 fetuses with hydrencephalus had been observed per litter in the background data (the mean incidence is $1.4 \%$ ) and that 2 fetuses with hydrencephalus had been observed per litter in artificially inseminated or mated rabbits, hydrencephalus at $1000 \mathrm{mg} / \mathrm{kg} \mathrm{bw} /$ day was considered not to be attributable to administration of the drug. Other than the above, the frequencies of external, visceral, and skeletal abnormalities were comparable between all of the dose groups and the control group.

As there were no toxicological findings related to administration of the drug in dams or fetuses in any of the dose groups, the NOAEL in this study was considered to be $1000 \mathrm{mg} / \mathrm{kg} \mathrm{bw} /$ day, the highest dose in this study, for dams and fetuses. Flutianil showed no teratogenicity.
Neurotoxicity ${ }^{21)}$

\section{Acute neurotoxicity}

A neurotoxicity screening battery indicated that the acute should be tested to the limit dose of $2 \mathrm{mg} / \mathrm{kg}$. In the 90 -day repeated oral dose toxicity study in rats, ${ }^{7)}$ no effects were observed at the highest dose tested, $20000 \mathrm{ppm}$. The $20000 \mathrm{ppm}$ dose was measured at 1270 and $1500 \mathrm{mg} / \mathrm{kg}$ in the 30-day toxicity study.

Subchronic neurotoxicity

Subchronic neurotoxicity has been evaluated at 90 days and at week 49 in the 2-year toxicity and carcinogenicity study in rats under dietary administration. ${ }^{15)}$ Evaluations were conducted for motor activity, grip strength, and sensory motor responses and weekly for the FOBs. The highest dose tested in the subchronic study was $20000 \mathrm{ppm}(1271 / 1500 \mathrm{mg} / \mathrm{kg}$ in the male/female). The highest doses tested in the chronic study were $6000 \mathrm{ppm}$ in males and $20000 \mathrm{ppm}$ in females $(249 \mathrm{mg} / \mathrm{kg}$ /day for males and $1130 \mathrm{mg} / \mathrm{kg} /$ day for females). No neurological effects were observed in either longer term study.

The limit dose for subchronic neurotoxicity studies has been established at $1 \mathrm{mg} / \mathrm{kg}$. This dose has been exceeded in the 90-day study and for females in the 2-year study.

Table 8. Summary of genotoxicity studies (technical grade)

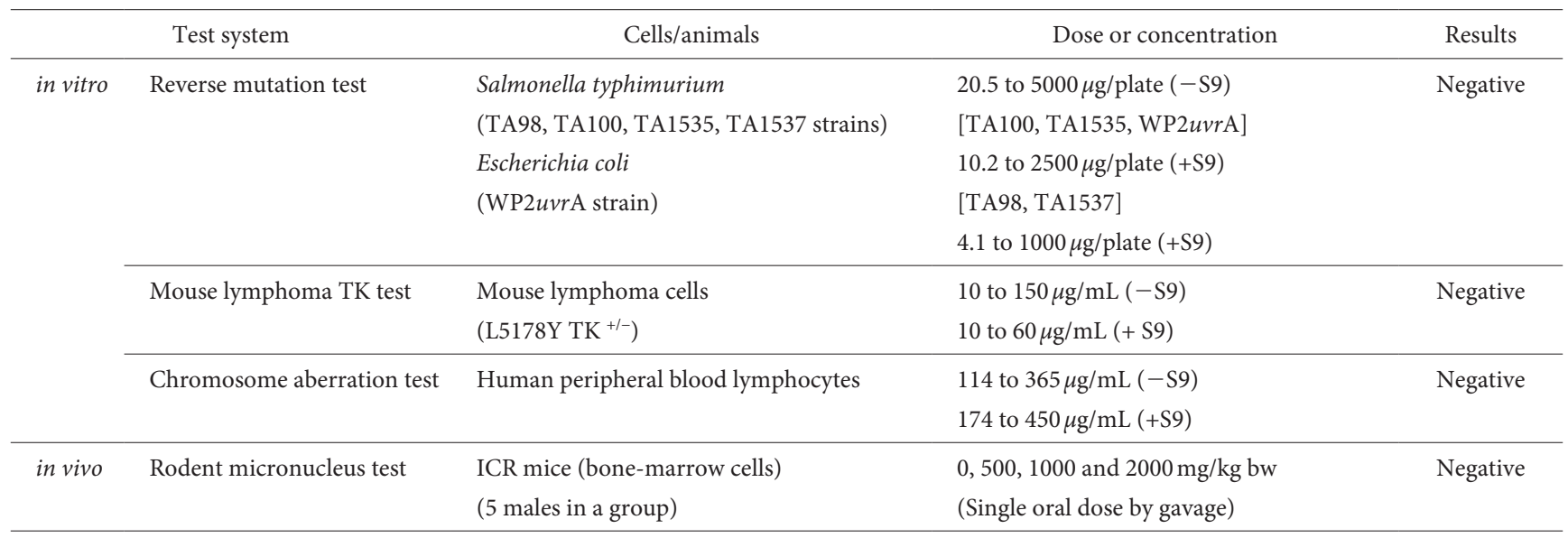

Note) ${ }^{+/}$S9: with/without exogenous metabolic activation 


\section{Genotoxicity $^{22-25)}$}

Flutianil (technical grade) was examined in the following in vitro and in vivo tests: bacterial reverse mutation assay, mouse lymphoma TK test, chromosomal aberration test using human peripheral blood lymphocytes, and a micronucleus test in mice.

As shown in Table 8, negative results were obtained from all tests, indicating that flutianil does not elicit genotoxicity.

\section{Conclusion}

We evaluated the effects of flutianil, an agricultural chemical, on foods and health using the data listed in the References.

Based on results of various toxicity studies, the effects of flutianil administration were mainly observed in the liver (increase in weight, hypertrophy of hepatocytes). Flutianil showed no neurotoxicity, carcinogenicity, reproductive toxicity, teratogenicity, or genotoxicity.

In the 90-day subacute toxicity study in rats, 2 -year combined chronic toxicity/carcinogenicity study, and two-generation reproductive study, deposition of hyaline droplets in the epithelial cells of the renal proximal tubule was observed in the kidney of males in all groups, including the control group, and the degree increased at high doses. As a result of immunostaining, this lesion was confirmed to be attributable to $\alpha 2 \mu$-globulin deposition. As $\alpha 2 \mu$-globulin is not produced in humans, $\alpha 2 \mu$-globulin nephropathy is considered to be a lesion specific to male rats that is not related to humans.

Table 9 shows the NOAEL and the LOAEL in each study. Of the NOAELs obtained from each study, the minimum

Table 9. NOAEL and LOAEL in each study

\begin{tabular}{|c|c|c|c|c|c|}
\hline $\begin{array}{l}\text { Animal } \\
\text { species }\end{array}$ & Study & Dose (mg/kgbw/day) & $\begin{array}{c}\text { NOAEL } \\
(\mathrm{mg} / \mathrm{kg} \text { bw/day })\end{array}$ & $\begin{array}{c}\text { LOAEL } \\
(\mathrm{mg} / \mathrm{kg} \text { bw/day })\end{array}$ & Remarks $^{a)}$ \\
\hline \multirow[t]{4}{*}{ Rat } & $\begin{array}{l}\text { 90-day subacute toxicity } \\
\text { study }\end{array}$ & $\begin{array}{l}\text { 0, 20, 200, 2000, } 20000 \mathrm{ppm} \\
\text { Male: } 0,1.22,12.5,122,1,270 \\
\text { Female: } 0,1.46,14.3,149,1500\end{array}$ & $\begin{array}{l}\text { Male: } 122 \\
\text { Female: } 1500\end{array}$ & $\begin{array}{l}\text { Male: } 1270 \\
\text { Female: - }\end{array}$ & $\begin{array}{l}\text { Male: An increase in relative weight of } \\
\text { the liver, centrilobular hepatocellular } \\
\text { hypertrophy } \\
\text { Female: No toxicological finding }\end{array}$ \\
\hline & $\begin{array}{l}\text { 2-year combined chronic } \\
\text { toxicity/carcinogenic- } \\
\text { ity study }\end{array}$ & $\begin{array}{l}\text { Male: } 0,60,600,2000,6000 \mathrm{ppm} \\
\text { Female: } 0,60,2000,6000,20000 \mathrm{ppm} \\
\text { Male: } 0,2.45,25.2,81.9,249 \\
\text { Female: } 0,3.15,111,334,1130\end{array}$ & $\begin{array}{l}\text { Male: } 249 \\
\text { Female: } 1130\end{array}$ & $\begin{array}{l}\text { Male: - } \\
\text { Female: - }\end{array}$ & $\begin{array}{l}\text { Male and Female: No toxicological finding } \\
\text { (Flutianil showed no carcinogenicity.) }\end{array}$ \\
\hline & $\begin{array}{l}\text { Two-generation } \\
\text { reproductive study }\end{array}$ & $\begin{array}{l}0,200,2000,20000 \mathrm{ppm} \\
\text { P male: } 0,13.9,142,1470 \\
\text { P female: } 0,16.6,171,1750 \\
\mathrm{~F}_{1} \text { male: } 0,15.2,155,1580 \\
\mathrm{~F}_{1} \text { female: } 0,17.1,176,1770\end{array}$ & $\begin{array}{l}\text { Parent animals } \\
\text { P male: } 142 \\
\text { P female: } 171 \\
\mathrm{~F}_{1} \text { male: } 155 \\
\mathrm{~F}_{1} \text { female: } 176 \\
\text { Offspring } \\
\text { P male: } 1470 \\
\text { P female: } 1750 \\
\mathrm{~F}_{1} \text { male: } 1580 \\
\mathrm{~F}_{1} \text { female: } 1770\end{array}$ & $\begin{array}{l}\text { Parent animals } \\
\text { P male: } 1470 \\
\text { P female: } 1750 \\
\mathrm{~F}_{1} \text { male: } 1580 \\
\mathrm{~F}_{1} \text { female: } 1770 \\
\text { Offspring } \\
\text { P male: — } \\
\text { P female: — } \\
\mathrm{F}_{1} \text { male: — } \\
\mathrm{F}_{1} \text { female: - }\end{array}$ & $\begin{array}{l}\text { Parent animals } \\
\text { Male and Female: Increases in absolute } \\
\text { and relative weights of the liver, etc. } \\
\text { Offspring } \\
\text { Male and female: No toxicological finding } \\
\text { (Flutianil showed no effect on reproduc- } \\
\text { tion.) }\end{array}$ \\
\hline & $\begin{array}{l}\text { Developmental toxicity } \\
\text { study }\end{array}$ & $0,100,333,1000$ & $\begin{array}{l}\text { Dam: } 1000 \\
\text { Fetus: } 1000\end{array}$ & $\begin{array}{l}\text { Dam: - } \\
\text { Fetus: - }\end{array}$ & $\begin{array}{l}\text { Dam: No toxicological finding } \\
\text { Fetus: No toxicological finding } \\
\text { (Flutianil showed no teratogenicity.) }\end{array}$ \\
\hline \multirow[t]{2}{*}{ Mouse } & $\begin{array}{l}\text { 90-day subacute toxicity } \\
\text { study }\end{array}$ & $\begin{array}{l}0,1000,3000,10000 \mathrm{ppm} \\
\text { Male: } 0,138,409,1390 \\
\text { Female: } 0,159,481,1560\end{array}$ & $\begin{array}{l}\text { Male: } 1390 \\
\text { Female: } 1560\end{array}$ & $\begin{array}{l}\text { Male: - } \\
\text { Female: - }\end{array}$ & Male and female: No toxicological finding \\
\hline & $\begin{array}{l}\text { 18-month carcinogenic- } \\
\text { ity study }\end{array}$ & $\begin{array}{l}0,1000,3000,10000 \mathrm{ppm} \\
\text { Male: } 0,106,321,1084 \\
\text { Female: } 0,105,316,1063\end{array}$ & $\begin{array}{l}\text { Male: } 1084 \\
\text { Female: } 1063\end{array}$ & $\begin{array}{l}\text { Male: - } \\
\text { Female: - }\end{array}$ & $\begin{array}{l}\text { Male and female: No toxicological finding } \\
\text { (Flutianil showed no carcinogenicity.) }\end{array}$ \\
\hline Rabbit & $\begin{array}{l}\text { Developmental toxicity } \\
\text { study }\end{array}$ & $0,100,300,1000$ & $\begin{array}{l}\text { Dam: } 1000 \\
\text { Fetus: } 1000\end{array}$ & $\begin{array}{l}\text { Dam: - } \\
\text { Fetus: - }\end{array}$ & $\begin{array}{l}\text { Dam: No toxicological finding } \\
\text { Fetus: No toxicological finding } \\
\quad \text { (Flutianil showed no teratogenicity.) }\end{array}$ \\
\hline \multirow[t]{2}{*}{ Dog } & $\begin{array}{l}\text { 90-day subacute toxicity } \\
\text { study }\end{array}$ & $0,30,300,1000$ & $\begin{array}{l}\text { Male: } 1000 \\
\text { Female: } 1000\end{array}$ & $\begin{array}{l}\text { Male: - } \\
\text { Female: - }\end{array}$ & Male and female: No toxicological finding \\
\hline & $\begin{array}{l}\text { 1-year chronic toxicity } \\
\text { study }\end{array}$ & $0,30,300,1000$ & $\begin{array}{l}\text { Male: } 1000 \\
\text { Female: } 1000\end{array}$ & $\begin{array}{l}\text { Male: - } \\
\text { Female: - }\end{array}$ & Male and female: No toxicological finding \\
\hline
\end{tabular}

—: NOAEL or LOAEL could not be set. ${ }^{a)}$ Summary of the toxicological findings observed at the LOAEL is shown in the remark. 
value was $2000 \mathrm{ppm}$ (flutianil consumption in males and females was $122 \mathrm{mg} / \mathrm{kg}$ bw/day and $142 \mathrm{mg} / \mathrm{kg}$ bw/day, respectively) in the 90 -day subacute toxicity study in rats and the two-generation reproductive study, and the toxicological findings observed in the two-generation reproductive study were similar to those observed in the 90-day subacute toxicity study. Meanwhile, the NOAEL in the 2-year combined chronic toxicity/carcinogenicity study was $6000 \mathrm{ppm}(249 \mathrm{mg} / \mathrm{kg} \mathrm{bw} /$ day $)$. This difference in NOAELs is considered to be attributable to the difference in dose setting; in addition, considering that the 2-year combined chronic toxicity/carcinogenicity study was longer than the 90-day subacute toxicity study, the NOAEL in rats is considered to be valid at $249 \mathrm{mg} / \mathrm{kg}$ bw/day. The Food Safety Commission of Japan $^{26)}$ established the acceptable daily intake (ADI) as $2.4 \mathrm{mg} /$ $\mathrm{kg}$ bw/day with a safety factor of 100 based on the NOAEL of $249 \mathrm{mg} / \mathrm{kg}$ bw/day in the 2-year combined chronic toxicity/carcinogenicity study in rats.

\begin{tabular}{ll}
\hline ADI & $\begin{array}{l}2.4 \mathrm{mg} / \mathrm{kg} b w / \text { day } \\
\text { (Data providing basis for ADI) }\end{array}$ \\
$\begin{array}{l}\text { Combined chronic toxicity/ } \\
\text { carcinogenicity study }\end{array}$ \\
(Animal) & Rats \\
(Period) & 2 years \\
(Administration method) & $\begin{array}{c}\text { Administration of diets con- } \\
\text { taining flutianil }\end{array}$ \\
(NOAEL) & $249 \mathrm{mg} / \mathrm{kg}$ bw/day \\
(Safety factor) & 100 \\
\hline
\end{tabular}

\section{References}

1) Acute oral toxicity study in rats: Product Safety Labs, 2015.

2) Acute dermal toxicity study in rats: Product Safety Labs, 2015.

3) Acute inhalation toxicity study in rats: Covance Laboratories Ltd. (UK), 2008.

4) Primary skin irritation test in rabbit: Bozo Research Center Co., Ltd. 2009.

5) Primary eye irritation test in rabbit: Bozo Research Center Co., Ltd. 2009.

6) Skin sensitization test in guinea pigs: Bozo Research Center Co., Ltd.
2009.

7) 90-day repeated oral dose toxicity study in rats: Institute of Environmental Toxicology, 2009.

8) K. N. M. Khan and C. L. Alden: "Handbook of Toxicologic Pathology (2nd edition)," ed. by W. M. Haschek, C. G. Rousseaux, and M. A. Walling, Academic Press, New York, pp.255-336, 2002.

9) J. A. Swenberg and L. D. Lehman-McKeeman: "Species Differences in Thyroid, Kidney and Urinary bladder Carcinogenesis," eds. by C. C. Capen, E. Dybing, J. M. Rice, and J. D. Wilbourn, IARC Scientific Publications, Lyon, No.147, pp.95-118, 1999.

10) A. M. Doi, G. Hill, J. Seely, J. R. Hailey, G. Kissling and J. R. Bucher: Toxicol. Pathol. 35, 533-540 (2007).

11) 90-day repeated oral dose toxicity study of in mouse: Institute of Environmental Toxicology, 2009.

12) 90-day repeated oral dose toxicity study in beagle dogs: Bozo Research Center Co., Ltd. 2009.

13) 28-day repeated dermal dose toxicity study of in rats: Covance Laboratories Ltd, (UK), 2008.

14) 52-week chronic toxicity study in beagle dogs by gavage administration: Bozo Research Center Co., Ltd. 2010.

15) 2-year toxicity and carcinogenicity study in rats by dietary administration: Institute of Environmental Toxicology, 2009.

16) Carcinogenicity study in mouse by dietary administration: Institute of Environmental Toxicology, 2009.

17) Reproductive toxicity study in rats: Institute of Environmental Toxicology, 2009.

18) OK-5203: Historical Control Data in IET (Rat chronic/carcinogenicity and reproduction data): Institute of Environmental Toxicology, 2014.

19) Teratogenicity study in rats: CR-DDS Co., Ltd. (USA), 2006.

20) Teratogenicity study in rabbits: WIL Research Laboratories Co., Ltd. (USA), 2007.

21) Waiver Request for Neurotoxicity for Flutianil Technical: Landis International, Inc., 2012, unpublished.

22) Bacterial reverse mutation assay: Covance Laboratories Ltd. (UK), 2005.

23) In vitro chromosomal aberration test using human capillary blood lymphocyte cultured cell: Covance Laboratories Ltd. (UK), 2005.

24) Gene mutation assay using mouse lymphoma cell: Covance Laboratories Ltd. (UK), 2005.

25) Mouse micronucleus test: Biotoxtech Co., Ltd. (Korea), 2008.

26) http://www.fsc.go.jp/fsciis/evaluationDocument/show/ kya20161114141 